\title{
Localization of type I interferon in murine trophoblast and decidua during decidual formation
}

\author{
Y. Yamamoto, M. Kurohmaru and Y. Hayashi \\ Department of Veterinary Anatomy, Faculty of Agriculture, University of Tokyo, Bunkyo-ku, \\ Tokyo 113, Japan
}

\begin{abstract}
Summary. Mouse trophoblast and decidua were examined by means of immunohistochemistry to define the localization of type I interferon. The decidua were stained for type I interferon at the time of implantation. The strong reaction was first observed in the primary decidual zone on day 5 and subsequently in the secondary decidual zone on day 6. After day 10 , the decidua basalis and decidua capsularis showed a strong reaction.

At the one-cell stage, embryos were weakly labelled, but a positive reaction was recognized in compacted morulae. Blastocysts on days 3 and 4 were positive in trophoblast and inner cell mass and a strong reaction was observed in the primitive endoderm on day 4. The visceral endoderm on day 5 and the trophoblast on day 6 were positive. After day 10 , the trophoblast giant cells, labyrinth, visceral yolk sac and fetal blood cells gave a positive reaction.

This study is the first demonstration of type I interferon localization in situ in mouse trophoblast and decidua during decidual formation.
\end{abstract}

Keywords: type I interferon; implantation; decidualization; trophoblast; mouse

\section{Introduction}

Implantation and placentation are essential processes of reproduction in all mammals except the monotremes. These events have immunological implications, as mammalian embryos have different genotypes from their mothers. Some hypotheses have been proposed to explain why embryos are not rejected by their mothers: for example, embryos lack major histocompatibility complex (MHC) class I antigens at the time of implantation (Sellens, 1977; Desoye et al., 1988); murine trophoblast resists lysis by allospecific, cytotoxic T lymphocytes (Zuckermann \& Head, 1987), and natural killer cells that may injure murine embryos are inactivated by prostaglandin derived from murine decidua (Scodras et al., 1990). Because these hypotheses are incomplete, the strategies by which embryos escape from maternal rejection have still to be defined.

Interferons are powerful, inducible, effector molecules with a wide spectrum of regulatory functions (Romeo et al., 1989). The existence of type I interferon in human and murine placental tissues has suggested that it may play a role in regulating feto-maternal relationships (Fowler et al., 1980, Bocci et al., 1985; Duc-Goiron et al., 1985; Chard et al., 1986; Howatson et al., 1988). Although the presence of type I interferon was reported in the syncytiotrophoblast and the maternal decidua of human placenta, its origin and function are unknown.

In this study, the localization of type I interferon in murine trophoblast and decidua during decidual formation was examined by immunohistochemistry. Its possible role in preventing maternal rejection of the embryo is discussed. 


\section{Materials and Methods}

\section{Animals}

Virgin female mice, 8-12 weeks old, from the inbred strain C57BL/10ScSc (Japan SLC, Hamamatsu, Japan) were mated with males of a similar age of the inbred strain C57BL/10BRSSgSn (Institute of Medical Science, University of Tokyo, Japan). All animals were maintained on a standard programme of $14 \mathrm{~h}$ light:10 h dark. The day on which vaginal plugs were found was designated as day 0 . Female mice at each stage were anaesthetized with pentobarbital and $0.9 \% \mathrm{NaCl}$ solution was perfused through the heart followed by $50 \mathrm{ml}$ of Carnoy's fixative at $4^{\circ} \mathrm{C}$. Uteri were surgically excised from mice during the normal oestrous cycle and on days $0,1,2,3,3 \cdot 75,4,5,6,8,10$ and 16, and oviducts were excised from mice on days 0,1 and 2 . The tissues were fixed in the same fixative for $1.5 \mathrm{~h}$ and dehydrated in absolute ethanol at $4^{\circ} \mathrm{C}$. They were immersed in polyesterwax:ethanol, $1: 1(\mathbf{P}: \mathrm{E}=1: 1)$ at $37^{\circ} \mathrm{C}$ for $1.5 \mathrm{~h}$ and in $P: E=9: 1$ at $37^{\circ} \mathrm{C}$ for $1.5 \mathrm{~h}$ and finally embedded in $P: E=9: 1$. Sections were cut at $4 \mu \mathrm{m}$.

\section{Immunohistochemical procedures}

Immunohistochemistry was carried out at room temperature using rabbit antimouse $\alpha$ and $\beta$-interferon antiserum (Paesel, Frankfurt, Germany) as the first antibody. The activity of the antiserum is $1.0 \times 10^{4} \mathrm{NIH}$ Neutralizing Reference Units $\mathrm{ml}^{-1}$. The sections were immersed in absolute ethanol for $5 \mathrm{~min}$ to remove polyesterwax. They were then rehydrated through a series of ethanols, washed with distilled water and rinsed with 0.01 mol phosphate-buffered saline $1^{-1}$ (PBS, $\mathrm{pH} 7 \cdot 2$ ). The sections were incubated in the following reagents: $1 \%$ bovine serum albumin (BSA) in PBS for 15 min; rabbit antimouse $\alpha$ and $\beta$-interferon antiserum (1:500 dilution) for $2 \mathrm{~h}$; PBS wash; $1 \%$ BSA in PBS for $15 \mathrm{~min}$; biotinylated goat antirabbit immunoglobulin G (Organon Teknika NV-Cappel Products, USA) for $45 \mathrm{~min}$; PBS wash; $1 \% \mathrm{BSA}$ in PBS for $15 \mathrm{~min}$; avidin-biotin complex (Vector Laboratories Inc., Burlingame, CA, USA) for $45 \mathrm{~min}$; and PBS wash. Afterwards, they were stained with $0.5 \mathrm{mg}$ diaminobenzidine $\mathrm{ml}^{-1}$ in PBS containing $0.1 \%$ hydrogen peroxide and counterstained with haematoxylin. For negative controls, (i) normal rabbit serum and (ii) rabbit antimouse $\alpha$ and $\beta$-interferon antiserum that had been incubated with 1300 -fold unit excess of mouse $\alpha$-interferon (Lee Biomolecular Research Lab., Inc., San Diego, USA) for $45 \mathrm{~min}$ at $4^{\circ} \mathrm{C}$ were used instead of the antiserum.

\section{Results}

Little reaction for type I interferon was observed in the uterus during the normal oestrous cycle or on days $0,1,2$ and 3, except for a weak reaction in the cell membrane and cytoplasm of luminal and glandular epithelia (Fig. 1a). However, in the uterus at the time of implantation on day 4, most of the decidualized cells showed diffuse labelling of type I interferon in the cytoplasm (Fig. Ib). There were also a few stromal cells, distant from the attached blastocyst, which were morphologically decidualized, but showed weak labelling. Endometrial stromal cells that had not been decidualized showed little reaction. The labelling in luminal and glandular epithelia became slightly stronger and these tissues continued to react for type I interferon during pregnancy. Six hours before the stage of day 4, a small proportion of uterine endometrial stromal cells was decidualized and type I interferon was detected in the cytoplasm of these cells. In uteri on day 5 , the primary decidual zone (PDZ) and secondary decidual zone (SDZ) showed positive staining in the cytoplasm. The staining of the PDZ was more intense than that of the SDZ (Fig. 1c). In uteri on days 6 and 8, there was increased staining over a wide area of the SDZ. In uteri after day 10, the decidua basalis and decidua capsularis were intensely positive in the cytoplasm, and decidual tissue neighbouring trophoblast giant cells showed an especially strong reaction (Fig. le). The reaction of the decidua was stronger than that of the fetal trophoblast. No reaction was observed in controls using normal rabbit serum and rabbit antimouse $\alpha$ and $\beta$-interferon antiserum absorbed with mouse $\alpha$-interferon (Fig. 1d).

One-cell embryos on day 0 showed little reaction for type I interferon (Fig. 2a), but 2-cell embryos on day 1 were weakly positive. The labelling of type I interferon gradually increased in the cytoplasm of compacted morulae (Fig. 2b). Blastocysts on day 3 were strongly positive in the cytoplasm of the trophoblast and inner cell mass (Fig. 2c). In hatched blastocysts on day 4, the trophoblast and inner cell mass was weakly labelled, and the primitive endoderm reacted 

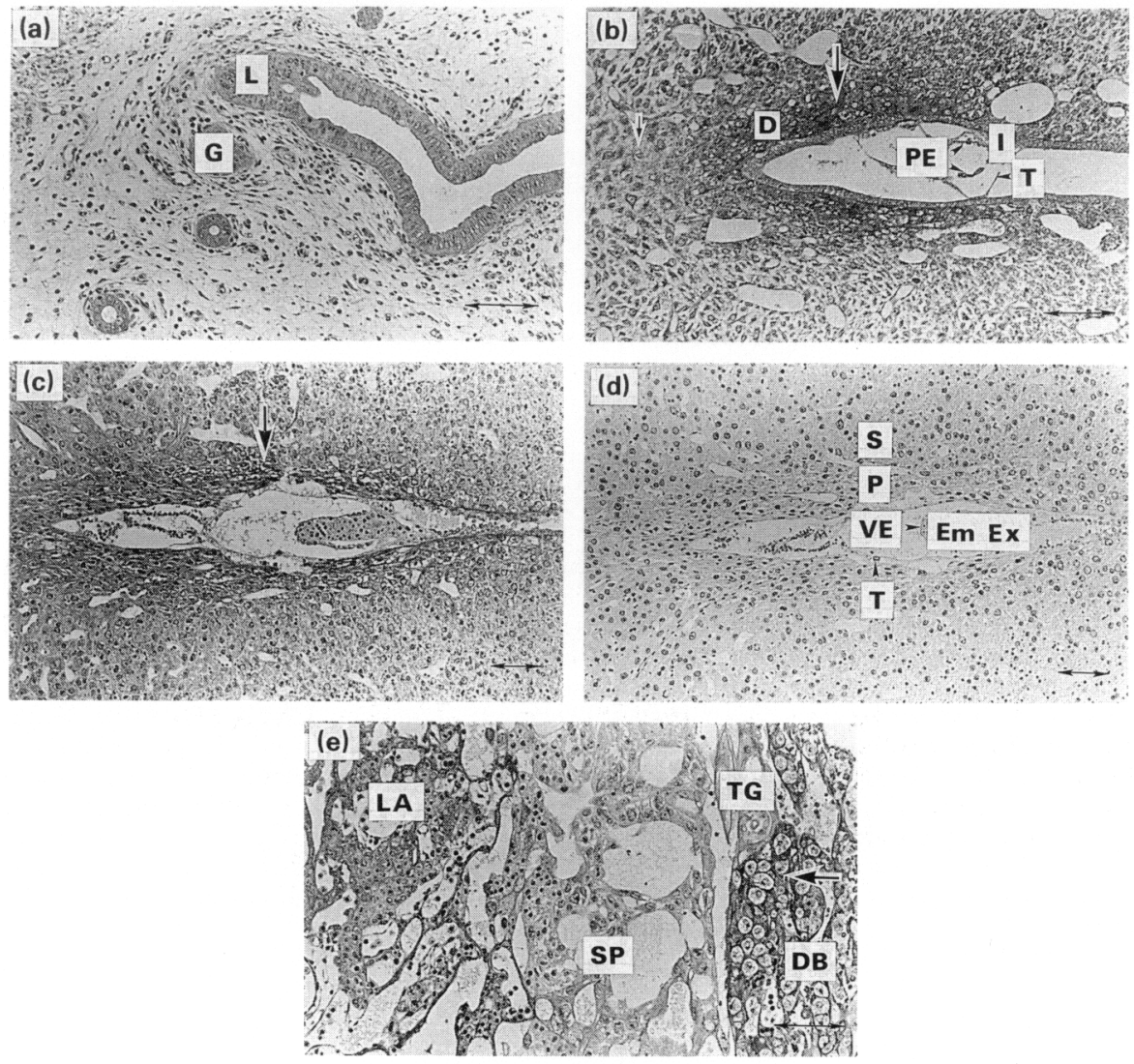

Fig. 1. Localization of type I interferon in mouse uteri during the normal oestrous cycle and pregnancy $($ bar $=100 \mu \mathrm{m}$ ): (a) weak labelling was observed only in luminal and glandular epithelia in a proestrous uterus; L: luminal epithelium; G: glandular epithelium; (b) positive staining was observed in most of the decidualized cells (large arrow) and blastocyst on day 4 . There were also stromal cells that were morphologically decidualized, but showed little labelling (small arrow). In blastocyst, the reaction of primitive endoderm was evident; $D$ : decidua; T: trophoblast; I: inner cell mass; PE: primitive endoderm; (c) positive reaction was observed in primary and secondary decidual zones and visceral endoderm of the embryo on day 5. The reaction of the primary decidual zone was strong (arrow); (d) negative control at the stage of day 5 using normal rabbit serum; P: primary decidual zone; S: secondary decidual zone; T: trophoblast; VE: visceral endoderm; Em: embryonic ectoderm; Ex: extra-embryonic ectoderm; (e) decidua basalis, trophoblast giant cells and labyrinth on day 10 were positive. Decidua basalis neighbouring trophoblast giant cells showed a strong reaction (arrow). Spongiotrophoblast was negative; DB: decidua basalis; TG: trophoblast giant cell; SP: spongiotrophoblast; LA: labyrinth.

prominently (Fig. 1b). In embryos on day 5, little labelling was observed in the trophoblast and embryonic and extra-embryonic ectoderm, while a clear reaction was detected in the cytoplasm and blastocoelic cell membrane of the visceral endoderm (Fig. 1c). In embryos on day 6, although the reaction in the cytoplasm of the trophoblast increased, the labelling in the cytoplasm of the visceral endoderm appeared to decrease. The ectoplacental cone and other embryonic tissues showed little labelling. On day 8, a strong reaction was exhibited not only in the cytoplasm of the trophoblast, but also in the cytoplasm and cell membrane of the visceral yolk sac. After day 10, there were reactions in the cytoplasm of the trophoblast giant cells and the cytoplasm and cell membrane of the labyrinth. The cytoplasm and cell membrane of the visceral yolk sac and the cytoplasm of fetal 

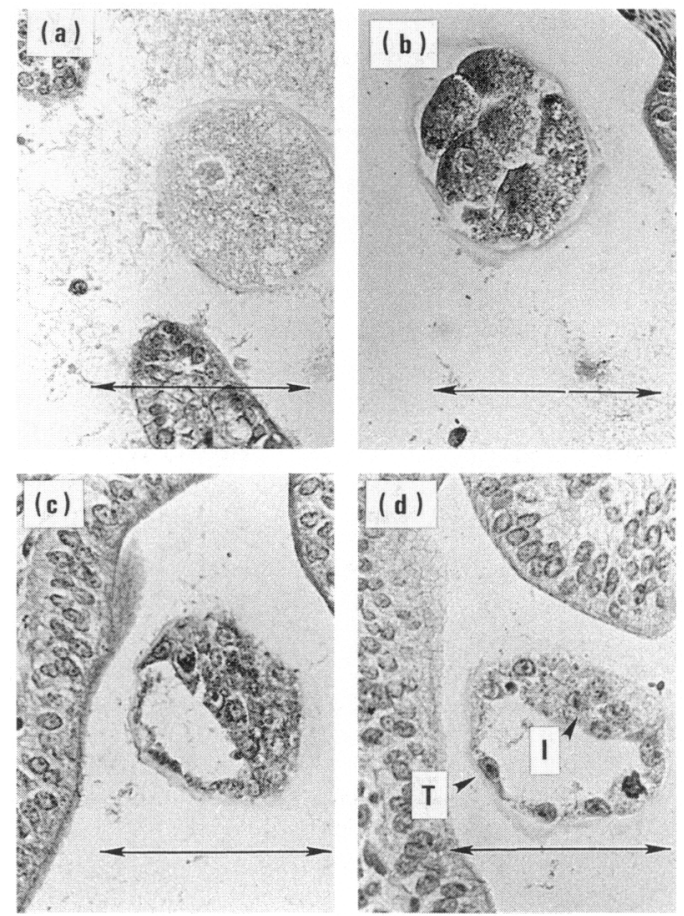

Fig. 2. Reaction of type I interferon in mouse preimplantation embryos (bar $=100 \mu \mathrm{m})$ : (a) little reaction was observed in one-cell embryos on day 0 ; (b) positive reaction was observed in a morula on day 2; (c) strong reaction was observed in trophoblast and inner cell mass of an early blastocyst on day 3 ; (d) negative control at the stage of day 3 using normal rabbit serum; T: trophoblast; I: inner cell mass.

blood cells were also positive. The reaction in the labyrinth increased as the pregnancy proceeded. The spongiotrophoblast, which has been reported to react for paternal MHC class I antigens (Redline \& Lu, 1989), showed little reaction (Fig. 1e). These results are summarized in Tables 1 and 2.

Table 1. Reaction of type I interferon during the preimplantation period in mice

\begin{tabular}{lcc}
\hline Stage & Endometrial stroma & Embryo \\
\hline Day 0 & - & - \\
Day 1 & - & + \\
Day 2 & - & + \\
Day 3 & - & + \\
Day 4 & + & + \\
\hline
\end{tabular}

\section{Discussion}

In the present study, type I interferon appeared in murine decidua at the time of implantation and in murine trophoblast at the early blastocyst stage on day 3. Judging by the intensity of immunostaining, the quantity of type I interferon seemed to be regulated during pregnancy. That is, the 
Table 2. Decidual, embryonic or fetal tissue stained for type I interferon during decidual formation in mice

\begin{tabular}{|c|c|c|}
\hline Stage & Decidual tissue & $\begin{array}{l}\text { Embryonic or } \\
\text { fetal tissue }\end{array}$ \\
\hline Day 4 & Decidua & Primitive endoderm \\
\hline Day 5 & $\begin{array}{l}\mathrm{PDZ}^{*} \\
\mathrm{SDZ}+\end{array}$ & Visceral endoderm \\
\hline Day 6 & $\begin{array}{l}\text { PDZ } \\
\text { SDZ }\end{array}$ & Trophoblast \\
\hline Day 8 & SDZ & $\begin{array}{l}\text { Trophoblast } \\
\text { Visceral yolk sac }\end{array}$ \\
\hline Day 10 & $\begin{array}{l}\text { Decidua basalis } \\
\text { Decidua capsularis }\end{array}$ & $\begin{array}{l}\text { Trophoblast giant cell } \\
\text { Labyrinth } \\
\text { Visceral yolk sac } \\
\text { Fetal blood cells }\end{array}$ \\
\hline Day 16 & $\begin{array}{l}\text { Decidua basalis } \\
\text { Decidua capsularis }\end{array}$ & $\begin{array}{l}\text { Trophoblast giant cell } \\
\text { Labyrinth } \\
\text { Visceral yolk sac } \\
\text { Fetal blood cells }\end{array}$ \\
\hline
\end{tabular}

*PDZ, primary decidual zone.

$\uparrow$ SDZ, secondary decidual zone.

reaction for type I interferon in the primary decidual zone on day 5 was stronger than that in the early decidua on day 4 , and the reaction in the secondary decidual zone increased as the pregnancy proceeded. The labelling in the blastocyst decreased at the time of implantation. The labelling in the trophoblast increased again after day 6 and the reaction in the labyrinth increased after day 10 . However, it appeared that type I interferon was uniformly present at the embryo-maternal and feto-maternal interfaces throughout pregnancy.

It has been suggested that type I interferon may play an important role in regulating fetomaternal relationships (Chard et al., 1986). Further, it is well known that interferons prolong the survival of allografts (Mobraaten et al., 1973; Hirsch et al., 1974). These results suggest that type I interferon in murine decidua and trophoblast may be essential for maternal acceptance of embryos and fetuses.

Type I interferon in the decidua appeared at the time of implantation. This interferon does not seem to be a trigger in the decidualization of stromal cells, since the molecule became detectable after day 4 , when these cells had already become decidualized in their morphology. It has been reported that $\alpha$-interferon does not induce decidualization in suitably sensitized uteri in mice (Baker \& Nieder, 1990).

Luminal and glandular epithelia reacted for type I interferon during the normal oestrous cycle and pregnancy. Type I interferon in these tissues may be involved in the normal physiological status of uteri.

Type I interferon was also detected in murine preimplantation embryos. The strongest reaction was observed at the early blastocyst stage. The trophoblast of ungulate blastocysts has been reported to synthesize and release $\alpha$-interferon during the peri-implantation period, and the molecule has been shown to have an antiluteolytic function (Imakawa et al., 1987; Cross \& Roberts, 1989; Gnatek, 1989; Lifsey et al., 1989; Roberts, 1989; Farin et al., 1990). In mouse embryos, however, it is unclear whether the type I interferon has antiluteolytic activity or not, since luteolysis occurs in different ways in mice and ungulates.

Although the function of type $I$ interferon in murine preimplantation embryos is unknown, interferons are reported to affect cell proliferation and differentiation (Romeo et al., 1989). 
As embryos undergo cell proliferation and differentiation at the preimplantation stage, type I interferon may exert an important controlling influence on cell proliferation and differentiation in embryos. Baker \& Nieder (1990) did not detect interferon activity in the conditioned-mediacontaining proteins secreted from murine peri-implantation blastocysts and in the lysed blastocysts, but some proteins with molecular masses in the range of murine $\alpha$-interferon were demonstrated in the conditioned media. The quantity of type I interferon may have been too small to be detected in their bioassay system, despite its presence in murine embryos as demonstrated by the present study.

Nonpolymorphic MHC class I antigens have been detected in human cytotrophoblast and rat basal trophoblast (Ellis, 1990; Ellis et al., 1990; Kanbour-Shakir, 1990). These antigens are thought to have important roles at the feto-maternal interface. In mice, however, polymorphic classical MHC class I antigens are reported to be detected on the cell surface of spongiotrophoblast (Redline \& Lu, 1989). Zuckermann \& Head (1986) found that MHC class I antigens on the cell surface of murine trophoblast were induced by $\alpha / \beta$-interferon (type I interferon) or $\gamma$-interferon (type II interferon) in vitro. There is a strong possibility that these $\mathrm{MHC}$ antigens may be induced in vivo by type I interferon produced by the trophoblast giant cells, labyrinth and decidua. More detailed research is necessary to ascertain the significance of type I interferon at the embryo-maternal and feto-maternal interfaces.

The authors wish to thank I. Tsugiyama (Department of Veterinary Anatomy, Faculty of Agriculture, University of Tokyo) for expert care in keeping the laboratory mice.

This work was supported by the Basic Research Core System, the Special Coordination Fund for Promoting Science and Technology in Japan.

\section{References}

Baker, D.J. \& Nieder, G.L. (1990) Interferon activity is not detected in blastocyst secretions and does not induce decidualization in mice. Journal of Reproduction and Fertility 88, 307-313.

Bocci, V., Paulesu, L. \& Ricci, M.G. (1985) The physiological interferon response: IV. Production of interferon by the perfused human placenta at term. Proceedings of the Society for Experimental Biology and Medicine 180, 137-143.

Chard, T., Craig, P.H., Menabawey, M. \& Lee, C. (1986) Alpha interferon in human pregnancy. British Journal of Obstetrics and Gynaecology 93, $1145-1149$.

Cross, J.C. \& Roberts, R.M. (1989) Porcine conceptuses secrete an interferon during the preattachment period of early pregnancy. Biology of Reproduction 40, 1109-1118.

Desoye, G., Dohr, G.A., Motter, W., Winter, R., Urdl, W., Pusch, H., Uchanska-Ziegler, B. \& Ziegler, A. (1988) Lack of HLA class I and class II antigens on human preimplantation embryos. Journal of Immunology 140, 4157-4159.

Duc-Goiran, P., Robert-Galliot, B., Lopez, J. \& Chany, C. (1985) Unusual apparently constitutive interferons and antagonists in human placental blood. Proceedings of the National Academy of Sciences USA 82, $5010-5014$.

Ellis, S. (1990) HLA G: at the interface. American Journal of Reproductive Immunology 23, 84-86.

Ellis, S.A., Palmer, M.S. \& McMichael, A.J. (1990) Human trophoblast and the choriocarcinoma cell line BeWo express a truncated HLA class I molecule. Journal of Immunology 144, 731-735.
Farin, C.E., Imakawa, K., Hansen, T.R., McDonnell, J.J., Murphy, C.N., Farin, P.W. \& Roberts, R.M. (1990) Expression of trophoblastic interferon genes in sheep and cattle. Biology of Reproduction 43,210-218.

Fowler, A.K., Reed, C.D. \& Giron, D.J. (1980) Identification of an interferon in murine placentas. Nature 286, 266-267.

Gnatek, G.G., Smith, L.D., Duby, R.T. \& Godkin, J.D. (1989) Maternal recognition of pregnancy in the goat: effects of conceptus removal on interestrus intervals and characterization of conceptus protein production during early pregnancy. Biology of Reproduction 41, 655-663.

Hirsch, M.S., Ellis, D.A. \& Black, P.H. (1974) Immunosuppressive effects of an interferon preparation in vivo. Transplantation 17, 234-236.

Howatson, A.G., Farquharson, M., Meager, A., McNicol, A.M. \& Foulis, A.K. (1988) Localization of $\alpha$ interferon in the human feto placental unit. Journal of Endocrinology 119, 531-534.

Imakawa, K., Anthony, R.V., Kazemi, M., Marotti, K.R., Polites, H.G. \& Roberts, R.M. (1987) Interferon-like sequence of ovine trophoblast protein secreted by embryonic trophectoderm. Nature 330, 377-379.

Kanbour-Shakir, A., Zhang, X., Rouleau, A., Armstrong, D.T., Kunz, H.W., Macpherson, T.A. \& Gill, T.J., III ( 1990$)$ Gene imprinting and major histocompatibility complex class I antigen expression in the rat placenta. Proceedings of the National Academy of Sciences USA 87, 444- 448 .

Lifsey, B.J., Jr, Baumbach, G.A. \& Godkin, J.D. (1989) Isolation, characterization and immunocytochemical 
localization of bovine trophoblast protein-1. Biology of Reproduction 40, 343-352.

Mobraaten, L.E., Maeyer, E.D. \& Maeyer-Guignard, J.D. (1973) Prolongation of allograft survival in mice by inducers of interferon. Transplantation 16, 415-420.

Redline, R.W. \& Lu, C.Y. (1989) Localization of fetal major histocompatibility complex antigens and maternal leukocytes in murine placenta. Implications for maternal-fetal immunological relationship. Laboratory Investigations 61, 27-36.

Roberts, R.M. (1989) Conceptus interferons and maternal recognition of pregnancy. Biology of Reproduction $\mathbf{4 0}$, 449-452.

Romeo, G., Fiorucci, G. \& Rossi, G.B. (1989) Interferons in cell growth and development. Trends in Genetics $\mathbf{5}$, 19-24.
Scodras, J.M., Parhar, R.S., Kennedy, T.G. \& Lala, P.K. (1990) Prostaglandin-mediated inactivation of natural killer cells in the murine decidua. Cellular Immunology 127, 352-367.

Sellens, M.H. (1977) Antigen expression on early mouse trophoblast. Nature 269, $60-61$.

Zuckermann, F.A. \& Head, J.R. (1986) Expression of MHC antigens on murine trophoblast and their modulation by interferon. Journal of Immunology 137, 846-853.

Zuckermann, F.A. \& Head, J.R. (1987) Murine trophoblast resists cell-mediated lysis. I. Resistance to allospecific cytotoxic $\mathrm{T}$ lymphocytes. Journal of Immunology 139, 2856-2864.

Received 18 April 1991 